\title{
Odour modification in salmon hydrolysates using the Maillard reaction
}

\author{
Christelle Kouakou, ${ }^{\mathrm{a}, \mathrm{b}}$, Jean-Pascal Berge ${ }^{\mathrm{b}}$, Régis Baron ${ }^{\mathrm{b}}$, Laurent Lethuaut ${ }^{\mathrm{a}}$, Carole Prost $^{\mathrm{a}}$ and \\ Mireille Cardinal ${ }^{\mathrm{b}}$,
}

\author{
a LUNAM University, ONIRIS, UMR 6144 GEPEA, Flavour Research Unit, Nantes, France \\ ${ }^{b}$ IFREMER, Laboratory of Science and Technology of Marine Biomass, F-44311, Nantes 03 , France \\ *: Corresponding author : Mireille Cardinal, tel.: +33240374061; fax: +33240374071; \\ email address : Mireille.Cardinal@ifremer.fr
}

\begin{abstract}
:
The aim of this work was to study the effect of adding sugar during proteolysis to promote the Maillard reaction and mask the initial fish odor and off-flavors generated. An experimental design, based on the Doehlert plan, was used to study the influence of hydrolysis conditions (time, temperature, sugar, and antioxidant addition) on the odor characteristics of hydrolysates, soluble protein levels, and amino acid content. Results showed that the lowest level of sugar (10g of D-xylose added to $1 \mathrm{~kg}$ of by-products) was enough to develop a grilled odor in hydrolysates. In the hydrolysis conditions used, i.e. enzyme inactivation at $95^{\circ} \mathrm{C}$ for $30 \mathrm{~min}$, hydrolysis temperature had no effect on grilled odor production but significantly affected the soluble protein fraction, as did hydrolysis time. Soluble protein content and essential amino acid content increased with the enzymatic reaction but were not modified by adding sugar. Hydrolysis conditions that promote Maillard reactions while keeping a nutritional balance have been identified.
\end{abstract}

Keywords: Salmon by-product ; Hydrolysate ; Maillard reaction ; Sensory characteristics ; off flavor ; Soluble protein

\section{Introduction}

In the European Union, filleting, salting, and smoking fish generates a considerable amount of solid waste and by-products (50-75\% of the fish), with a total of 3.17 million tons per year (Ferraro et al., 2010). Discharged waste and by-products are currently rising, driven by both a net increase in consumption of fishery products and changing consumer trends, with preferences for ready-to-use products rising. However, seafood by-products and major waste (heads, viscera, skin, and backbones) are underused, often creating disposal problems and environmental concerns (Perez-Galvez et al., 2009). At the same time, processors can no longer discard offal directly into marine waters, resulting in high disposal costs. Instead of wasting this raw material, strategies for upgrading by-products have already been identified. Among them, enzymatic hydrolysis appears efficient as a means of recovering the valuable components from marine 


\section{ACCEPTED MANUSCRIPT}

biomass and their conversion into marketable and acceptable forms (Dumay et al., 2006; 2009; Gildberg, 1993; Sathivel et al., 2003; Sylla et al., 2008; Kechaou et al., 2009; Nguyen et al., 2011; Randriamahatody et al., 2011). Enzymatic proteolysis has been found to be a valuable bioprocess for enhancing the functional properties of the original protein without diminishing its nutritive value (Gbogouri et al., 2004). Thus, on the basis of their good functional properties and nutritional value, fish protein hydrolysates (FPH) are widely used as nutritional ingredients. In feed, and notably aquafeed, they are considered as one of the best ways of supplying high protein content and palatability-enhancing agents (Refstie et al., 2004; Aguila et al., 2007; Nguyen et al., 2012). In the food sector, protein hydrolysates in general, and FPH in particular, may have a wide range of applications, such as ingredients in formulated food (Mahmoud et al., 1992; Clemente, 2000; Frøkjaer, 1994), functional ingredients (Kristinsson and Rasco, 2000), nutritional additives (Yáñez et al., 1976), and flavoring applications (Shahidi, 1998; Baek and Cadwallader, 1995). However, hydrolyzing protein from seafood often goes hand in hand with undesirable effects (Kilara, 1985). The dominant fish flavor is sometimes associated with a rancid odor and/or flavor, limiting its use in the food industry (Sylla, 2009).

To reduce or mask the natural fish odor in the products, sugar can be added to the by-product to promote a Maillard reaction (MR) and thus improve the sensory quality. The MR is a complex series of chemical interactions that reduce sugar and amino acids, peptides, or proteins, resulting in a variety of by-products, intermediates, and brown products (melanoidins), which play an important role in the aroma, taste, and color of processed foods (Lertittikul et al. , 2007). At the terminal stage, the Maillard reaction generates a wide variety of molecules and flavors associated with connotations of roasted caramel, which is known to stimulate the appetite. As mentioned by 


\section{ACCEPTED MANUSCRIPT}

Mancilla-Margalli and Lopez (2002), since Ruckdeschel in 1914 spoke on aroma generation via Maillard pathways, the food industry has patented flavor formation processes from the heated aqueous mixtures of amino acids and reducing sugars (Sun et al., 2010). It is strongly influenced by factors such as temperature, time, initial $\mathrm{pH}$, and water activity (Ajandouz et al., 2001). Of these factors, temperature is one of the most important parameters affecting the reaction rates and aroma characteristics of foods (Labuza and Baisier, 1992). Such reactions usually occur during the processing and storage of foods, producing many Maillard reaction products (MRPs), including volatile compounds of low molecular mass, non-volatile colored compounds of intermediate molecular mass, and brown substances of high molecular weight. MRPs can be generated from the proteins or peptides of salmon by-products and used as flavor enhancers to modify the sensory quality of the hydrolysates. However, the information regarding the MRPs prepared using salmon by-product hydrolysates and their application is still limited. In addition, the MR often has negative consequences on the nutritional value (amino acid and protein unavailability for human metabolism) (Lerici et al., 1990). Producing seafood flavors from underused fish species through protein hydrolysis is somewhat challenging because of the difficulty in ensuring high organoleptic quality. Until now, only a few studies have tested the effects of masking agents on fish oil emulsions and shown that a combination of vanillin and apple flavor was able to mask the fishy odor (Serfert et al., 2010). The purpose of this study was to investigate the effect on odor characteristics and the nutritional value of the products by adding sugar under hydrolysis conditions. The aim of this work was to identify the hydrolysis conditions which could promote MRs with the production of sweet notes and aromatic compounds able to mask the fish aroma without affecting the intrinsic nutritional qualities. The 


\section{ACCEPTED MANUSCRIPT}

impact of process conditions (hydrolysis time and temperature) and adding antioxidants and/or sugar on odor and biochemical properties was tested using an experimental design methodology.

\section{Materials and methods}

\subsection{Raw material}

Salmon by-products (heads and frames) were obtained from a local smoked salmon company (Piriac, France), whose supplier was Shetland Organic Salmon from the Framgord Society in Scotland. The by-products recovered after filleting the fresh fish were collected at the end of one day of processing. The by-products, held chilled in insulated containers with ice, were immediately transferred to the laboratory, minced in a UM 40 E-GN3 cutter (Stephan, IMA, Lognes, France) for $5 \mathrm{~min}$, vacuum-packed, and quickly frozen at $-40{ }^{\circ} \mathrm{C}$ in a horizontal plate freezer. The samples were then stored at $-20^{\circ} \mathrm{C}$ until further analysis.

\subsection{Enzymes and additives}

The enzyme reaction is produced by a protease, $\operatorname{Protamex}^{\circledR}$ (E.C. 3.4.21.62/ 3.4.24.28), which is a Bacillus protease complex provided by the Danish company Novozymes (Bagsvaerd, Denmark) and stored at $4{ }^{\circ} \mathrm{C}$ until used. Protamex ${ }^{\circledR}$ was developed to hydrolyze food proteins and satisfies the purity requirements for food-grade enzymes, as set by the Joint FAO/WHO Expert Committee on Food Additives (JECFA) and the Food Chemicals Codex (FCC). The optimal working conditions for Protamex ${ }^{\circledR}$ are reported to be $\mathrm{pH}$ 5.5-7.5 at a temperature of between 35

and $60{ }^{\circ} \mathrm{C}$. Protamex ${ }^{\circledR}$ has a declared activity of 1.5 Anson Units (AU) $\mathrm{g}^{-1}$ (Novo Nordisk AS, 


\section{ACCEPTED MANUSCRIPT}

Bagsvaerd, Denmark). To protect against oxidation of the hydrolysates, a commercial mixture of natural antioxidants (tocopherols and rosemary) from the company Jan Dekker International (Saint Germain en Laye, France) was used. Of all the sugars available for promoting flavor generation (Ames et al., 2001), xylose was chosen for economic and technological reasons. Xylose was provided by Danisco (Brabrand, Denmark).

\subsection{Enzymatic hydrolysis}

Figure 1 outlines the overall process used in the production of salmon by-product hydrolysates. Frozen minced by-products were thawed at $4^{\circ} \mathrm{C}$ for 14 hours. Seven hundred g of salmon byproducts were mixed with $350 \mathrm{ml}$ of water $(2: 1 ; \mathrm{w}: \mathrm{v})$. The result was hydrolyzed in a closed bioreactor of 1 liter capacity, stirred with constant agitation $(250 \mathrm{rpm})$. Hydrolysis was begun by adding $0.15 \%$ of $\mathrm{w} / \mathrm{w}$ Protamex ${ }^{\circledR}$ and minced salmon by-products, water, sugar, and antioxidants. The mixture was made directly in the bioreactor with a double jacket to make thermal exchanges (heating or cooling) possible. The hydrolysis reaction was stopped by heating the product at $95^{\circ} \mathrm{C}$ for $30 \mathrm{~min}$. The hydrolysates were then cooled on ice at room temperature and centrifuged at $9800 \mathrm{~g}$ at $15^{\circ} \mathrm{C}$ for $30 \mathrm{~min}$ in a Beckman coulter to collect aqueous fraction. Samples were stored at $-80^{\circ} \mathrm{C}$ for further sensory and biochemical analyses (protein content; degree of hydrolysis; amino acids; browning).

\subsection{Experimental design}

Four processing variables were investigated: hydrolysis temperature, hydrolysis time, sugar, and antioxidant content. A D-optimal design was used with associated additional points in order to 


\section{ACCEPTED MANUSCRIPT}

refine the influence of the extreme points. According to preliminary studies based on a survey of the effective parameters, a Doehlert experimental design was selected (Ferreira et al., 2004). This matrix displayed a uniform distribution of the points within the experimental domain and allowed for a number of distinct levels for each variable. This experimental design structure made several structural validations possible during the modeling phase (linear and non-linear effects of variables and interactions between variables) while protecting the D-optimal criterion close to the minimum. The levels chosen for each factor are presented in Table 1. A supplementary sample was introduced as a control for sensory evaluation. This control sample was prepared without enzymes at a temperature of $60^{\circ} \mathrm{C}$, for a process time of $360 \mathrm{~min}$, without sugar and antioxidants. This made it possible to obtain a total of 41 samples. Response surface methodology (RSM) with a completely randomized factorial design was applied to optimize the hydrolysis conditions (Myers and Carter, 1989).

\subsection{Analytic methods}

\subsubsection{Protein content}

The total nitrogen content of the protein fraction was determined using the Kjeldahl method (Crooke and Simpson, 1971), expressed as the percentage of total nitrogen in the sample. Crude protein was estimated by multiplying the total nitrogen content $(\% \mathrm{~N})$ by a factor of 6.25 . 


\section{ACCEPTED MANUSCRIPT}

\subsubsection{Degree of hydrolysis (DH)}

The degree of hydrolysis is defined as the percent ratio of the number of peptide bonds broken (h) to the total number of peptide bonds per unit weight $\left(\mathrm{h}_{\text {tot }}\right)$. For every peptide bond hydrolyzed, a free $\alpha$ amino group is formed; $h_{\text {tot }}$ is the total number of peptide bonds in the protein $=8.6 \mathrm{eq} \mathrm{g} \mathrm{kg}^{-1}$ protein in fish samples (Novozymes, 2001). Measuring the DH means determining the number of free $\alpha$ amino groups based on the reaction between the Dinitrofluorobenzene (DNFB-Sanger reagent) and the amine group in amino acids (Goodwin, 1968). The reaction between DNFB and a free amino acid produces a dinitrophenyl amino acid (a yellow complex). Optical density is measured spectrophotometrically at $410 \mathrm{~nm}$.

\subsubsection{Determining amino acids}

Amino acid composition was analyzed by gas chromatography (GC-FID) using the method described by Kechaou et al. (2009). The amino acid analysis was performed using the EZ:faast ${ }^{\mathrm{TM}}$ procedure (Phenomenex, Torrance, CA, USA), consisting of a solid phase extraction step followed by derivatization and liquid/liquid extraction. An aliquot from the organic phase was analyzed on a GC-FID system (Perkin Elmer Autosystem XL, Waltham, MA, USA). The injector temperature was maintained at $250{ }^{\circ} \mathrm{C}$ while detection occurred at $320{ }^{\circ} \mathrm{C}$. Separation was achieved using a Zebron ZB-AAA GC column $(10 \mathrm{~m} \times 0.25 \mathrm{~mm})$ with the oven temperature increasing in a linear manner from 110 to $320^{\circ} \mathrm{C}$ at $32{ }^{\circ} \mathrm{C} / \mathrm{min}$. Helium was used as the carrier gas at a constant flow rate of $1.5 \mathrm{~mL} / \mathrm{min}$. The amino acids were quantified by their response factor relative to the internal standard norvaline added at a concentration of $200 \mu \mathrm{mol} / \mathrm{L}$.

\section{ACCEPTED MANUSCRIPT 8}




\section{ACCEPTED MANUSCRIPT}

\subsubsection{Measuring UV absorbance and browning}

The UV absorbance and browning of MRPs were measured according to the method developed by Ajandouz et al. (2001) to determine the intermediates in the MR. An appropriate dilution (25to 150 -fold dilution) was made using distilled water, and absorbance was measured at $294 \mathrm{~nm}$ by a spectrophotometer unicam.

\subsubsection{Sensory evaluation}

A descriptive analysis (ISO 13299, 2003) was performed to determine the differences in sensory characteristics between the 41 samples. The samples were sniffed by a trained panel of 11 people, 8 females and 3 males, selected from the internal sensory panel at IFREMER (Institut Français de Recherche pour l'Exploitation de la Mer). In the preliminary sensory sessions, the panelists were asked to describe the odor characteristics of a range of samples chosen to cover both the variations in process parameters and the possible variations in sensory characteristics. After selecting the discriminative and relevant descriptors, a discussion with the panelists made it possible to check the consensus on attribute selection and the associated definition. Nine descriptors of odor were chosen: global intensity, marine, fatty fish, dried fish, grilled, rancid, potato, sulphur, and brine fish. Two training sessions were organized to familiarize the panelists with the descriptors and harmonize their scores by comparing their own evaluation with the panel's mean score. Finally, the panelists carried out profiling tests and were required to score each descriptor on an unstructured scale anchored by the terms "low intensity" (0) and "high intensity" (10). The possible differences in color between the samples were masked with a black coloring agent that had a neutral smell. The hydrolysates (about $8 \mathrm{ml}$ ) were poured into a plastic 


\section{ACCEPTED MANUSCRIPT}

flask wrapped in aluminum foil and assigned a 3-digit number. Forty hydrolysates from the experimental design and a supplementary sample introduced as the control in each sensory session were evaluated by the panel. This sample made it possible to test the variability in the judges' sensory response during 7 sessions. Then, 47 samples were presented in seven sessions (6 or 7 products per session) at a rate of 2 sessions per week. An experimental design was constructed in order to balance the different effects tested in each session, such as whether or not sugar or antioxidants were present, time, and temperature of hydrolysis. The tests were performed in individual booths equipped with computers using data acquisition software (Fizz Biosystems, Couternon, France).

\subsection{Statistical analysis}

A two-way analysis of variance (ANOVA) was applied to the panelists' scores for each odor descriptor, with products and panelists as independent factors. Significant differences between means were determined using Duncan's multiple range test $(\mathrm{p}<0.05)$ (Meilgaard et al., 1991). A standardized Principal Component Analysis (PCA) was performed on the mean of the group score for each product and each descriptor to highlight the main odor characteristics of the products. The effect of process conditions on sensory characteristics and biochemical indicators was analyzed with a second order polynomial model with a first order interaction between factors. The main effects observed were summarized by the level of significance based on the ANOVA results (Statgraphics software, Sigma Plus, Paris, France). 


\section{ACCEPTED MANUSCRIPT}

\section{Results and discussion}

\subsection{Biochemical characteristics of hydrolysis}

\section{Protein solubilization and amino acid content}

By conducting hydrolysis with a large spectrum protease, it was expected that the soluble protein content would increase as the reaction progressed. For that purpose, certain biochemical parameters were followed.

The degree of hydrolysis is used to comprehensively evaluate both the action of enzymes on the substrate and the efficiency of the hydrolysis process. It indirectly provides information on the length of the resulting peptides and thus on their nutritional, functional, and sensory quality (Klompong et al., 2007). In our conditions, the resulting DH varied between $4.2 \%$ and $9.1 \%$ when no xylose was added and between $3.5 \%$ and $9 \%$ with xylose.

The resulting soluble protein content ranged between $7.2 \%$ and $11.5 \%$ (g.100 $\mathrm{g}^{-1}$ of wet weight) for proteolysis carried out without xylose and between $8.3 \%$ and $12 \%\left(\mathrm{~g} .100 \mathrm{~g}^{-1}\right.$ of wet weight) when xylose was added.

Except tryptophane, which is not preserved during the acid hydrolysis procedure, and arginine, which is not eluted by the column, 19 different amino acids (or related compounds) were detected and quantified. They ranged between $73.3 \mathrm{~g}$ and $95.9 \mathrm{~g}$ (100 $\mathrm{g}^{-1}$ of sample) for hydrolysates without xylose and $60.2 \mathrm{~g}$ and $91.0 \mathrm{~g}\left(100 \mathrm{~g}^{-1}\right.$ of sample) for hydrolysates with xylose. 


\section{ACCEPTED MANUSCRIPT}

In terms of concentrations, regardless of the conditions used, the most abundant amino acids in the hydrolysates were, in order, glycine $>$ glutamic acid $>$ asparagine $>$ proline $>$ alanine, and they accounted for at least half of the total number of amino acids (Table 2). Identifying the amino acids as FPH revealed that the ratio between essential amino acids (EAA) and total amino acids (TAA) varied between 28 and 34\% when no xylose was added and between 25 and 35\% with xylose during enzymatic hydrolysis.

Based on these results, it seems that in our conditions, adding xylose during hydrolysis did not affect the action of the Protamex, i.e. the cutting of proteins into smaller soluble parts (peptides or amino acids). Variance analysis effectively did not reveal any significant effect of xylose on either soluble protein content or amino acid ratio (Table 3).

\section{Maillard reaction setting:}

The progress of the MR was followed by measuring absorbance at $294 \mathrm{~nm}$. Measuring browning has long been an easy way of following the evolution of the MR in solutions. Its intensity is often used as an indicator of the extent to which the MR has taken place in foods, and it measures the advanced stage of the MR. Figure 2 shows the effect of xylose content and hydrolysis time on MR settings. Absorbance increased with hydrolysis time and sugar content. These results were in agreement with Yilmaz and Toledo (2005) who found that the color of MRP solutions was more dark-brown. It suggests that $\alpha$ and $\varepsilon$-amino functions brought by amino acids and peptides bound progressively to the carbonyl moiety as the hydrolysis time increased. The caramelization of sugars, which takes place at the same time, also plays a role in nonenzymatic browning reactions. In both the Maillard and caramelization reactions, highly UV- 


\section{ACCEPTED MANUSCRIPT}

absorbing and colorless compounds are formed at intermediate stages, whereas the brown polymers are formed in the final stages (Mauron, 1981).

\subsection{Sensory characteristics of hydrolysates}

A two-way analysis of variance performed on sensory data, with panelists and products as independent factors, made it possible to identify the descriptors with the most discriminative power. Comparing F values for the product effect showed that the grilled odor was the highest, followed in decreasing order by sulphur, global intensity, fatty fish, dried fish, potato, marine, rancid, and brine fish odor. To synthesize the main sensory characteristics of hydrolysates, a PCA with standardization was performed on the panel's mean scores obtained for each descriptor and each sample. The first principal component of this PCA, accounting for $51.7 \%$ of the total information, was created mainly by the grilled, dried fish, global intensity, marine, and fatty fish criteria (Figure 3) while sulphur, potato, and rancid odors were mostly involved in the creation of the second component (15.7\% of the total information). First of all, representing the products on the first plane of the PCA (Figure 4) showed that the control samples ( $\left.\mathrm{c}^{*}\right)$, which were evaluated at each sensory session, presented similar sensory characteristics. These samples were found in the same area, suggesting good repeatability in the panel and a certain confidence in the results. A clear separation between the samples appeared on this plane. Along axis 1, the products were separated according to the intensity of the roasted note: on the left of the figure were samples where sugar had been added during processing and on the right were samples without sugar added. This first result highlights the strong impact of sugar in developing roasted or grilled notes (Salmon et al., 1997). On axis 2, samples in the lower right quadrant of the figure

\section{ACCEPTED MANUSCRIPT 13}




\section{ACCEPTED MANUSCRIPT}

had odors described as fatty fish and rancid, while at the top, the samples were instead characterized by sulphur or potato notes. A rapid view of the processing parameters applied to these hydrolysates showed that temperature associated with time of processing could explain the differences between these two groups. Samples described as fatty fish and rancid were generally processed at a temperature above $40^{\circ} \mathrm{C}$ for a long time, when for other samples different combinations of time and temperature produced a variety of sensory characteristics. Sensory evaluation is often considered as a good evaluation method for the oxidation of products. Lipid oxidation directly affects product quality and is commonly associated with changes in flavor and texture in products (Ordóñez et al., 1999) and modifications to their smell or aroma. We observed that neither of the samples containing sugar was characterized by a rancid smell. Published reports have found a strong antioxidant activity from certain volatile compounds derived from the MR (Sumaya-Martinez et al., 2005), but it is more likely that the rancid notes generated were masked by the grilled odor produced by the MRs.

\subsection{Relationship between process conditions and the nutritional and sensory qualities of the hydrolysates}

The impact of processing conditions on quality parameters such as nutritional and sensory characteristics was investigated using analysis of variance with a generalized linear model. This model makes it possible to take into account the main effects, the interactions between variables, and the quadratic effects. Table 3 shows the significant effects observed for the processing parameters on biochemical parameters (soluble protein, amino acid ratio, absorbance at $294 \mathrm{~nm}$ ) 


\section{ACCEPTED MANUSCRIPT}

and on the sensory descriptors identified as the most discriminating (grilled odor, sulphur odor, fatty fish odor, and global intensity).

Regarding the proteins' solubilization, i.e. the effectiveness of the Protamex ${ }^{\circledR}$, of the processing parameters only temperature $(\mathrm{p}<0.01)$ and time $(\mathrm{p}<0.001)$ had any effect (Table 3$)$. For sugar, this influence could only be seen in an interaction with temperature $(p<0.01)$. As illustrated in Figure 5, and in our conditions, a temperature of between 45 and $50^{\circ} \mathrm{C}$ with a hydrolysis time of 4 to 6 hours led to higher recovery of soluble proteins.

Proteolysis is well-known as an effective method of recovering proteins in peptide forms with functional, biological, and nutritional interests (Randriamahatody, 2011). It also improves amino acid composition, thereby enhancing the nutritional quality of proteins. Before hydrolysis, EAA accounted for $19 \%$ of the TAA found in the soluble fraction. But, as previously observed (Kechaou et al., 2009) and expected, this proportion increased after proteolysis, regardless of the conditions used. At least $27 \%$ and up to $34 \%$ of the EAA were effectively found in the FPH. In addition to those EAA, certain other amino acids detected were of interest for foodstuffs. This was the case for some of the major amino acids quantified in the FPH, such as glycine, glutamic acid, aspartic acid, and alanine, which are known to be flavor enhancers (Heu et al., 2003; Jung et al., 2002)

From a sensory point of view, it appears that the global intensity of the odor was affected by the factors sugar, hydrolysis time, and hydrolysis temperature with a non-linear effect for the time factor (Table 3). Regarding the perception of the grilled odor, sugar and hydrolysis time had a linear and quadratic effect at significant levels of $p<0.001$ and $p<0.01$, respectively (Table 3 ). 


\section{ACCEPTED MANUSCRIPT}

From 0 to $10 \mathrm{~g} \cdot \mathrm{Kg}^{-1}$, there was a significant increase in the grilled note; the sensory scores ranged between 0 and 1 for samples without sugar and between 2.8 and 4.7 for the hydrolysate with $10 \mathrm{~g} \cdot \mathrm{Kg}^{-1}$; this increase became less so between 10 and $20 \mathrm{~g} \cdot \mathrm{Kg}^{-1}$. In this latter case, the grilled score ranged between 3.1 to 5.8 (Figure 6). The quadratic effect of hydrolysis time on the perception of a grilled smell is clearly illustrated in Figure 7, with the optimum between 200 and $300 \mathrm{~min}$. This duration seems necessary for enzymatic activity to release soluble amino acids and give access to the amine group for the carbonyl function of reducing sugars. Surprisingly, no effect of temperature hydrolysis was noticed for this sensory descriptor. This could be explained by the thermal inactivation of Protamex ${ }^{\circledR}$ that was performed in all the experiments at $95^{\circ} \mathrm{C}$ for half an hour. Such drastic thermal conditions may have been enough to initiate or speed up the MRs and thus mask the influence of hydrolysis temperature. As for temperature, no effect was observed after adding the antioxidants. From a practical point of view, adding $10 \mathrm{~g}$ of xylose to $1 \mathrm{~kg}$ of salmon by-product seems enough to reach a high intensity for the grilled note for 200-300 min of proteolysis carried out with Protamex ${ }^{\circledR}$, masking off flavor potential. For the sulphur descriptor, all factors except the antioxidants had significant effect on the production of this odor (Table 3). In Figure 4, it can be seen that the few samples characterized by this odor did not contain sugar and were mainly processed for a short hydrolysis time. However, the timetemperature interaction shows the possibility of obtaining this odor with other combined conditions such as a low temperature and a high hydrolysis time. For the fatty fish odor, the main effects observed were quadratic for sugar and interaction between time / temperature, time / sugar, and temperature / sugar. To decrease this odor, low temperatures and a short hydrolysis time or sugar additions are recommended (Machiels and Istasse, 2002).

\section{ACCEPTED MANUSCRIPT 16}




\section{ACCEPTED MANUSCRIPT}

As expected, processing parameters played an important role in the sensory perception of the resulting FPH. Adding sugar strongly modified this perception due to the production of MRPs. However, during the MR, $\alpha$ - and $\varepsilon$-amino functions brought about by the amino acids and peptides were progressively bound to the carbonyl function of reducing sugars present in the reaction medium (Laroque et al., 2008). These non-enzymatic reactions were responsible for numerous changes in the food properties. Although these reactions were of a great importance for producing aroma, taste, and color, they may be accompanied by a reduction in the nutritive value of the resulting foodstuffs.

\section{Conclusion}

The purpose of the study was to use sugar to initiate the MR and produce sweet notes and aromatic compounds able to mask the fish aroma without affecting intrinsic nutritional qualities. It was demonstrated that adding sugar during the proteolysis of salmon by-products could efficiently mask the perception of a fish odor in the resulting FPH by producing volatile compounds characterized by a grilled note. Complementary studies performed on the volatile formation but not presented here will help to understand the sensory scores achieved. Adding $10 \mathrm{~g}$ of xylose to $1 \mathrm{~kg}$ of salmon by-products was enough to initiate the MR and thus obtain a high intensity for the grilled note and is recommended from a practical point of view and also for a protecting effect on amino acid content. By using Protamex ${ }^{\circledR}$, with the aforementioned amount of xylose, for 240 to $300 \mathrm{~min}$ at a temperature ranging from 45 to $50^{\circ} \mathrm{C}$, a good compromise seems to have been found for maximizing the production of FPH from salmon by-products with no sensory perception of fish. These optimum process parameters based on experimental design in 


\section{ACCEPTED MANUSCRIPT}

laboratory conditions need a validation step before the scale up in production process. By using such FPH for feed or food purposes, we have highlighted a promising way of upgrading seafood waste, thus creating value-added compounds with high protein content that are well-balanced in terms of amino acids from a low-cost and underused raw material. However, as we also eat 'with our eyes', the significance of Maillard browning for consumer acceptance of foodstuffs is obvious and must thus be taken into account during development and formulation. Complementary work needs to be done to verify the bioavailability of these soluble peptides and to evaluate the possible production of aroma compounds in these "non-fishy" hydrolysates.

References

Aguila, J., Cuzon, G., Pascual, C., Domingues, P. M., Gaxiola, G., Sanchez, A., Maldonado, T., and Rosas, C. 2007. The effects of fish hydrolysate (CPSP) level on Octopus maya (Voss and Solis) diet: digestive enzyme activity, blood metabolites, and energy balance. Aquaculture 273 (4): 641-655.

Ajandouz, E. H., Tchiakpe, L. S., Ore, F. D., Benajiba, A., and Puigserver, A. 2001. Effects of pH on caramelization and Maillard reaction kinetics in fructose-lysine model systems. J. Food Sci. 66: 926-931.

Ames, J. M., Guy, R. C. E., and Kipping, G. J. 2001. Effect of pH, temperature, and moisture on the formation of volatile compounds in glycine/glucose model systems. J. Agri. Food Chem. 49 (9): 4315-4323.

Baek, H. H., and Cadwallader, K. R. 1995. Enzymatic hydrolysis of crayfish processing byproducts. J. Food Sci. 60(5): 929-935. 


\section{ACCEPTED MANUSCRIPT}

Clemente, A. 2000. Enzymatic protein hydrolysates in human nutrition. Trends Food Sci. Technol. 11(7): 254-262.

Crooke, W. M., and Simpson, W. E. 1971. Determination of ammonium in Kjeldahl digests of crops by an automated procedure. J. Agri. Food Chem. 27: 1256-1262.

Dumay, J., Donnay-Moreno, C., Barnathan, G., Jaouen P., and Bergé. J-P. 2006. Improvement of lipid and phospholipid recoveries from sardine (Sardina pilchardus) viscera using industrial proteases. Process Biochem. 41 (11):2327-2332.

Dumay, J., Allery, M., Donnay-Moreno, C., Barnathan, G., Jaouen, P., Carbonneau, M-E., and Berge, J-P. 2009. Optimization of hydrolysis of sardine (Sardina pilchardus) heads with Protamex: enhancement of lipid and phospholipid extraction. J. Sci. Food Agri. 89(9): 15991606.

FAO/WHO. 1990. Energy and protein requirements. Report of joint FAO/WHO/UNU expert consultation technical report. FAO/WHO and United Nations University, Geneva, Series no. 724: 116-129.

Ferraro, V., Cruz I. B., Jorge, R. F., F. Xavier Malcata, F. X., Pintado, M. E., Paula M.L. Castro, P. M. L. 2010. Valorisation of natural extracts from marine source focused on marine byproducts: A review. Food Research Int. 43: 2221-2233.

Ferreira S., Dos Santos W., Quintella C., Neto B., and Bosque-Sandra J. 2004. Doehlert matrix: a chemometric tool for analytical chemistry - a review. Talanta 63: 1061-1067.

Frøkjaer, S. 1994. Use of hydrolysate for protein supplementation. Food Technol. 48: 86-8. 


\section{ACCEPTED MANUSCRIPT}

Gbogouri, G. A., Linder, M., Fanni, J., and Parmentier, M. 2004. Influence of hydrolysis degree on the functional properties of salmon byproducts hydrolysates. J. Food Sci. 69: 615-622.

Gildberg, A. 1993. Enzymatic processing of marine raw materials. Process Biochem. 28: 1-15.

Goodwin, J. F. 1968. The colorimetric estimation of plasma amino nitrogen with DNFB. Clinical Chem. 14: 1080-1090.

Heu, M. S., Kim, J. S., and Shahidi, F. 2003. Components and nutritional quality of shrimp processing by-products. Food Chem. 82: 235-242.

ISO, InternationalOrganization for Standardization. 2003. Sensory Analysis-Methodology General Guidance for Establishing a Sensory Profile, ISO 13299, Geneva, Switzerland.

Jung, Nim, P., Watanabe, T., Endoh, K., Watanabe, K., and Abe, H. 2002. Taste-active components in a Vietnamese fish sauce. Fisheries Sci. 68: 913-920.

Kechaou, E. S., Dumay, J., Donnay-Moreno, C., Jaouen, P., Gouygou, J. P., Bergé, J. P., and Amar R, B. 2009. Enzymatic hydrolysis of cuttlefish (Sepia officinalis) and sardine (Sardina pilchardus) viscera using commercial proteases: Effects on lipid distribution and amino acid composition. J. Biosci. Bioengineer. 107 (2): 158-164.

Kilara, A. 1985. Enzyme-modified protein food ingredients. Process Biochem. 20: 149-158.

Klompong, V., Benjakul, S., Kantachote, D., and Shahidi, F. 2007. Antioxidative activity and functional properties of protein hydrolysate of yellow stripe trevally (Selaroides leptolepis) as influenced by the degree of hydrolysis and enzyme type. Food Chem. 102: 1317-27. 


\section{ACCEPTED MANUSCRIPT}

Kristinsson, H. G., and Rasco, B. A. 2000. Fish protein hydrolysates: production, biochemical and functional properties. Crit. Rev. Food Sci. Nut. 40: 43-81.

Labuza, T. P., and Baisier, W. M. 1992. The kinetics of nonenzymatic browning. Physical Chem. Foods 595-649.

Laroque, D., Inisan, C., Berger, C., Vouland, E., Dufossé, L., and Guérard, F. 2008. Kinetic study on the Maillard reaction. Consideration of sugar reactivity. Food Chem. 111 (4): 10321042.

Lerici, C. R., Barbanti, D., Manzano, M., and Cherubin, S. 1990. Early indicators of chemical changes in foods due to enzymic or nonenzymic browning reactions. 1: Study on heat-treated model systems. Lebensmittel Wissenschaft und Technologie. Food Sci. Technol. 23: 289-294.

Lertittikul, W., Benjakul, S., and Tanaka, M. 2007. Characteristics and antioxidative activity of Maillard reaction products from a porcine plasma protein-glucose model system as influenced by pH. Food Chem. 100(2): 669-677.

Machiels, D and Istasse, L. 2002. Maillard reaction: importance and applications in food chemistry, Annales de Médecine Vétérinaire, 146 (6): 347-352.

Mahmoud, M. I., Malone, W.T., and Cordle, C.T. 1992. Enzymatic hydrolysis of casein: effect of degree of hydrolysis on antigenicity and physical properties. J. Food Sci. 57: 1223-9.

Mancilla-Margalli, N. A. and Lopez, M. G. 2002. Generation of Maillard Compounds from Inulin during the Thermal Processing of Agave tequilana Weber Var. azul. J. Agric. Food Chem. 50: 806-812. 


\section{ACCEPTED MANUSCRIPT}

Mauron J. 1981. The Maillard reaction in food. A critical review from the nutritional standpoint. Programme Food Nutr. Sci. 5 (1): 5-35.

Meilgaard, D., Civille, G. V., and Carr, B. T. 1991. Sensory evaluation techniques (second edition), CRC Press, Boca Raton, FL.

Myers R., Khuri A., and Carter W. 1989. Response Surface Methodology : 1966-1988. Technometrics. 31 (2): 137-157.

Nguyen, H. T. M., Sylla, K. S. B., Randriamahatody, Z., Donnay-Moreno, C., Moreau, J., Luyen, T. T., and Berge, J-P. 2011. Enzymatic Hydrolysis of Yellowfin Tuna (Thunnus albacares) ByProducts Using Protamex Protease. Food Technol. Biotechnol. 49(1): 48-55.

Nguyen, H. T. M., Pérez-Gálvez, R., Bergé, J-P. 2012. Effect of diets containing tuna head hydrolysates on the survival and growth of shrimp Penaeus vannamei. Aquaculture. (324-325): $127-134$

Novo Nordisk AS, Protamex ${ }^{\mathrm{TM}}$ product sheet, B716d-GB, 1998.

Novozymes. 2001. Determination of the degree of hydrolysis (DH) based on OPA reaction. Novozymes

Ordóñez, J. A., Hierro, E. M., Bruna, J. M., and De la Hoz, L. 1999. Changes in the components of dry-fermented sausages during ripening. Crit. Rev. Food

Sci. Nut. 39, 329-367.

Perez-Galvez, R., and Berge J-P. 2009. General introduction about by-products, worldwide situation and French focus. In Added Value to Fisheries Waste (Jean-Pascal Bergé). 


\section{ACCEPTED MANUSCRIPT}

Randriamahatody, Z., Sylla, K. S. B., Nguyen, H. T. M., Donnay-Moreno, C., Razanamparany, L., Bourgougnon, N., and Bergé, J-P. 2011. Proteolysis of shrimp by-products (Peaneus monodon) from Madagascar Proteólisis de derivados de langostino (Peaneus monodon) de Madagascar. CyTA. J. Food 9: 220-228.

Refstie, S., Olli, J. J., and Standal, H. 2004. Feed intake, growth and protein utilization by postsmolt Alantic salmon (Salmo salar) in response to graded levels of fish protein hydrolysate in the diet. Aquaculture 239: 331-349.

Salmon, C. P., Knize, M. G., and Felton, J. S.1997. Effects of marinating on heterocyclic amine carcinogen formation in grilled chicken, Food Chem. Toxicol. 35(5): 433-441.

Sathivel, S., Bechtel, P. J., Babbitt, J., Smiley, S., Crapo, C., Reppond, K. D., and Prinyawiwatkul, W. 2003. Biochemical and functional properties of herring (Clupea harengus) byproduct hydrolysates. J. Food Sci. 68(7): 2196-2200.

Serfert, Y., Drusch, S., and Schwarz, K. 2010. Sensory odor profiling and lipid oxidation status of fish oil and microencapsulated fish oil. Food Chem. 123(4): 968-975.

Shahidi, F. 1998. Flavor of meat, meat products and seafood (2nd ed.). London, UK: Blackie Academic and Professional.

Sumaya-Martinez, M. T., Thomas, S., Linard, B., Binet, A., and Guerard, F. 2005. Effect

of Maillard reaction conditions on browning and antiradical activity of sugar-tuna stomach hydrolysate model system. Food Research Int. 38: 1045-1050. 


\section{ACCEPTED MANUSCRIPT}

Sun, W ., Zhao, M ., Cui, C., Zhao, Q., Yang, B. 2010. Effect of Maillard reaction products derived from the hydrolysate of mechanically deboned chicken residue on the antioxidant, textural and sensory properties of Cantonese sausages. Meat Sci. 86: 276-282.

Sylla, K. S. B., Musabyemariya, B., Berge, J-P., and Seydi, Mg. 2008. Water ratio effect on the proteins hydrolysis tongue sole by-products (Cynoglossus senegalensis). Revue Africaine de Santé et de Productions Animales (RASPA). 6(3-4): 189-194.

Sylla, K. S. B., Berge J-P, Prost, C., Musabyemariya, B., Seydi, Mg. (2009). Sensory and aromatic characteristics of tongue sole by-products hydrolysates (Cynoglossus senegalensis). Microbiologie et Hygiène Alimentaire. 21(60): 35-43.

Yáñez, E., Ballester, D., and Monckeberg, F. 1976. Enzymatic fish protein hydrolyzate:

Chemical composition, nutritive value and use as a supplement to cereal protein.

J. Food Sci. 41(6): 1289-1292.

Yilmaz, Y., and Toledo, R. 2005. Antioxidant activity of water-soluble Maillard reaction products. Food Chem. $93: 273-278$. 


\section{ACCEPTED MANUSCRIPT}

Table 1: Factors and experimental domain

\begin{tabular}{lcl}
\hline Independent variables & Levels & Experimental values \\
\hline Temperature $\left({ }^{\circ} \mathrm{C}\right)$ & 7 & $30 ; 35 ; 40 ; 45 ; 50 ; 55 ; 60$ \\
Time (min) & 7 & $30 ; 85 ; 140 ; 195 ; 250 ; 360 ; 470$ \\
Antioxidant $(\mathrm{ppm})$ & 6 & $32 ; 94 ; 125 ; 156 ; 219 ; 250$ \\
Sugar $\left(\mathrm{g} . \mathrm{kg}^{-1}\right)$ & 3 & 0,$10 ; 20$ \\
& & \\
\hline
\end{tabular}




\section{ACCEPTED MANUSCRIPT}

Table 2. Major amino acids quantified into FPH expressed as $\%\left(100 \mathrm{~g}^{-1}\right)$ on a dry weight basis.

\begin{tabular}{|c|c|c|c|c|c|}
\hline & & Mean & STD & Max & Min \\
\hline \multirow[t]{7}{*}{ EAA } & LEU & 5.92 & 0.33 & 6.72 & 5.28 \\
\hline & THR & 5.00 & 0.21 & 5.36 & 4.46 \\
\hline & LYS & 4.34 & 0.34 & 5.04 & 3.42 \\
\hline & ILE & 4.16 & 0.38 & 4.89 & 3.21 \\
\hline & PHE & 3.59 & 0.26 & 4.21 & 3.06 \\
\hline & VAL & 3.57 & 0.24 & 4.00 & 3.00 \\
\hline & MET & 3.15 & 0.18 & 3.53 & 2.82 \\
\hline \multirow[t]{2}{*}{ NEAA } & GLY & 15.72 & 1.05 & 17.51 & 13.67 \\
\hline & GLU & 10.86 & 0.86 & 13.02 & 9.28 \\
\hline
\end{tabular}




\section{ACCEPTED MANUSCRIPT}

$\begin{array}{lllll}\text { ASP } & 9.76 & 0.50 & 10.65 & 8.89 \\ \text { PRO } & 8.92 & 0.46 & 9.76 & 7.93 \\ \text { ALA } & 7.66 & 0.27 & 8.28 & 7.19 \\ & & & & \\ \text { SER } & 5.61 & 0.41 & 6.47 & 4.62 \\ & & & & \\ \text { HIS } & 2.92 & 0.21 & 3.41 & 2.45 \\ & & & & \\ \text { HYP } & 4.63 & 0.46 & 5.64 & 3.47 \\ & & & & \\ \text { TYR } & 2.07 & 0.25 & 2.70 & 1.53\end{array}$

EAA: essential amino acids NEAA: non-essential amino acids 


\section{ACCEPTED MANUSCRIPT}

Table 3. Effect of hydrolysis conditions on sensory characteristics and biochemical parameters

\begin{tabular}{|c|c|c|c|c|c|c|c|}
\hline & Biochemica & indicators & & & & Odors & \\
\hline $\begin{array}{l}\text { Processing } \\
\text { parameters }\end{array}$ & $\begin{array}{l}\text { Proteins } \\
\text { content }\end{array}$ & $\begin{array}{c}\text { EAA/TAA } \\
\text { ratio }\end{array}$ & $\begin{array}{c}\mathrm{DO} \\
294 \mathrm{~nm}\end{array}$ & Grilled & Sulphur & $\begin{array}{l}\text { Fatty } \\
\text { fish }\end{array}$ & $\begin{array}{l}\text { Global } \\
\text { intensity }\end{array}$ \\
\hline Time & $* * *$ & $* * *$ & $* * *$ & $* *$ & $* * *$ & - & $* *$ \\
\hline Temperature & $* *$ & - & - & - & $*$ & - & $* *$ \\
\hline Sugar & - & - & $* * *$ & $* * *$ & $*$ & - & $* * *$ \\
\hline Antioxidant & - & - & - & - & - & - & - \\
\hline Time*Time & $*$ & - & - & $* *$ & $* * *$ & $*$ & $* *$ \\
\hline Temp*Temp & $* * *$ & $*$ & - & - & - & & $* *$ \\
\hline Sugar*Sugar & - & - & - & $* * *$ & - & $*$ & - \\
\hline
\end{tabular}




\section{ACCEPTED MANUSCRIPT}

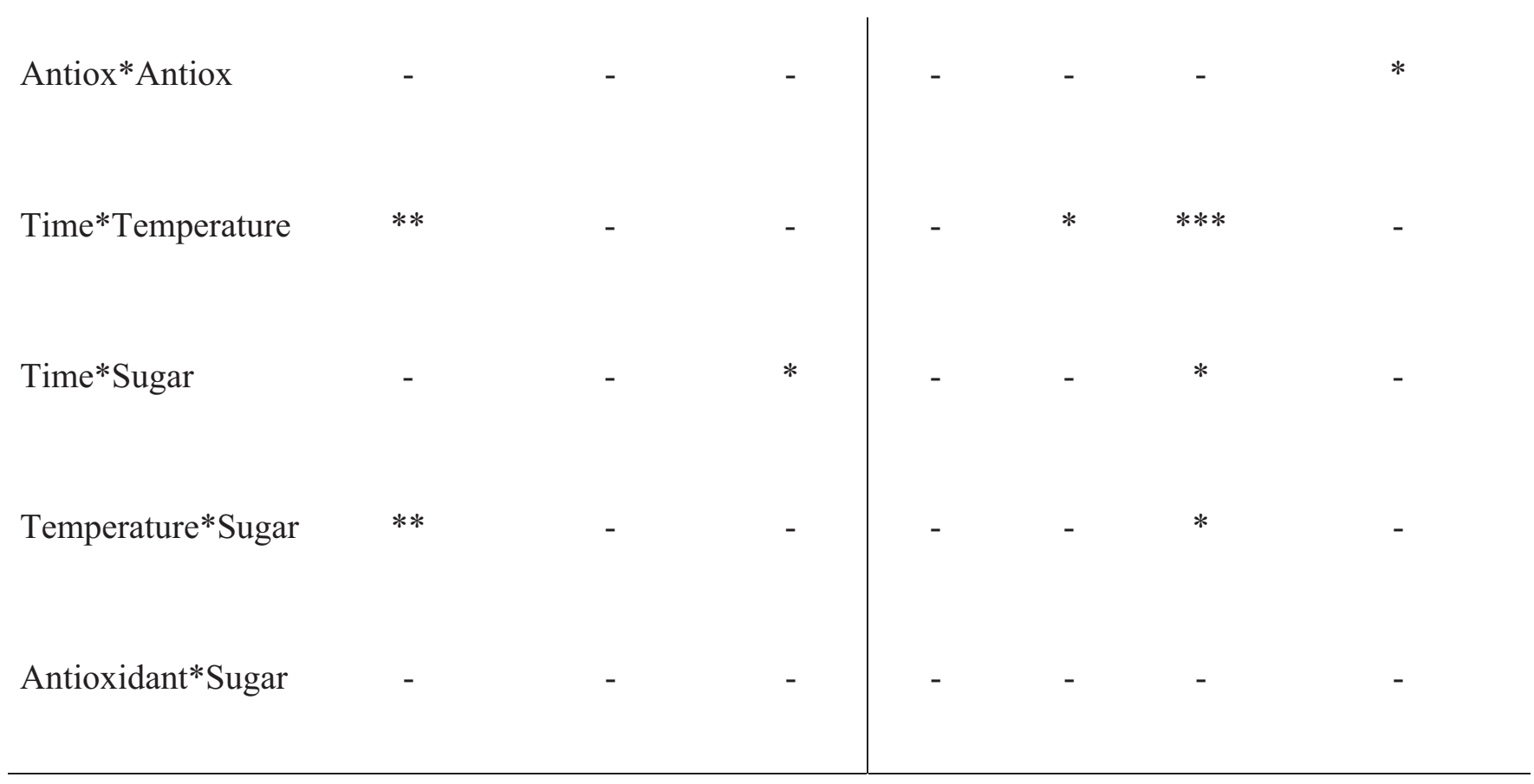

no significant effect: - ; significant effect: $*$ at $\mathrm{p} \leq 0.05 ;{ }^{* *}$ at $\mathrm{p} \leq 0.01 ; * * *$ at $\mathrm{p} \leq 0.001$ 


\section{ACCEPTED MANUSCRIPT}

Figure 1. Outline of a common procedure for by-product protein hydrolysate production

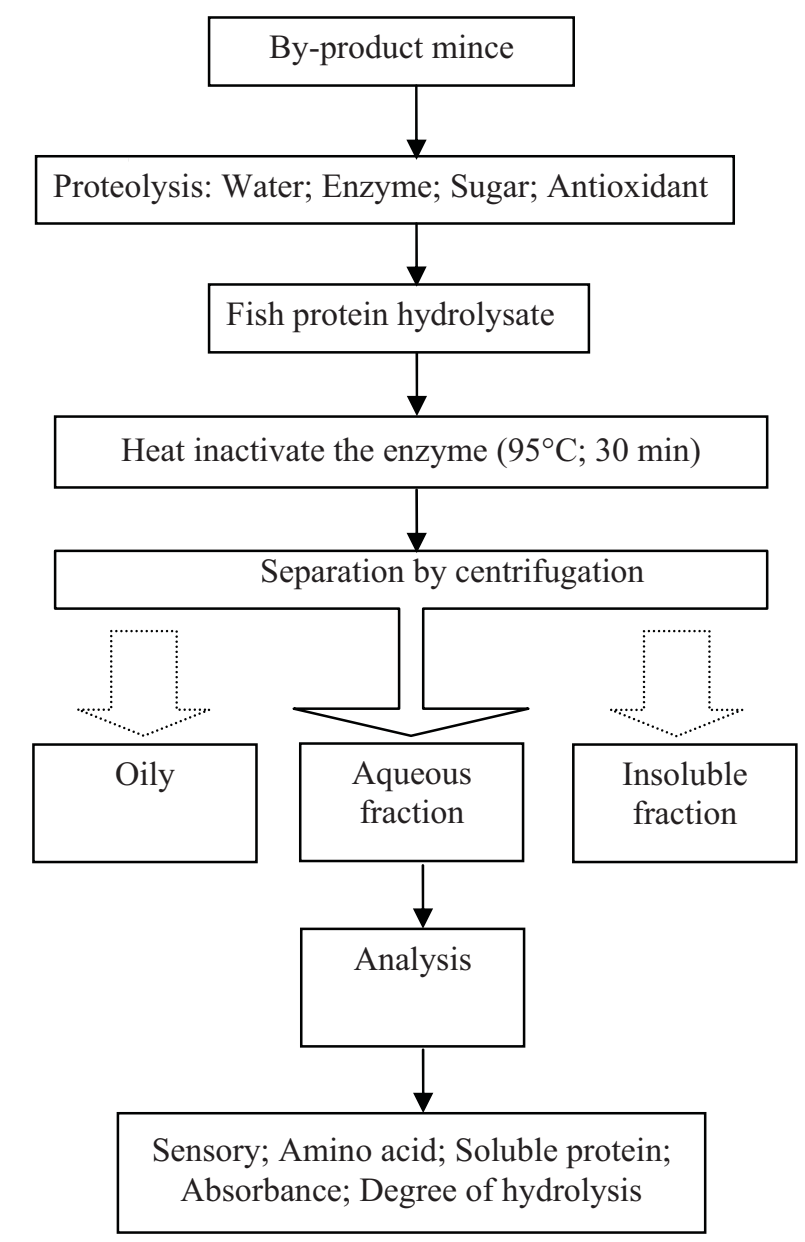

Conditions of hydrolysis: $30<$ Temperature $\left({ }^{\circ} \mathrm{C}\right)<60 ; 30<$ Time $(\min )<470$ 


\section{ACCEPTED MANUSCRIPT}

Figure2: Response surface for absorbance at $294 \mathrm{~nm}$ as a function of sugar and hydrolysis time

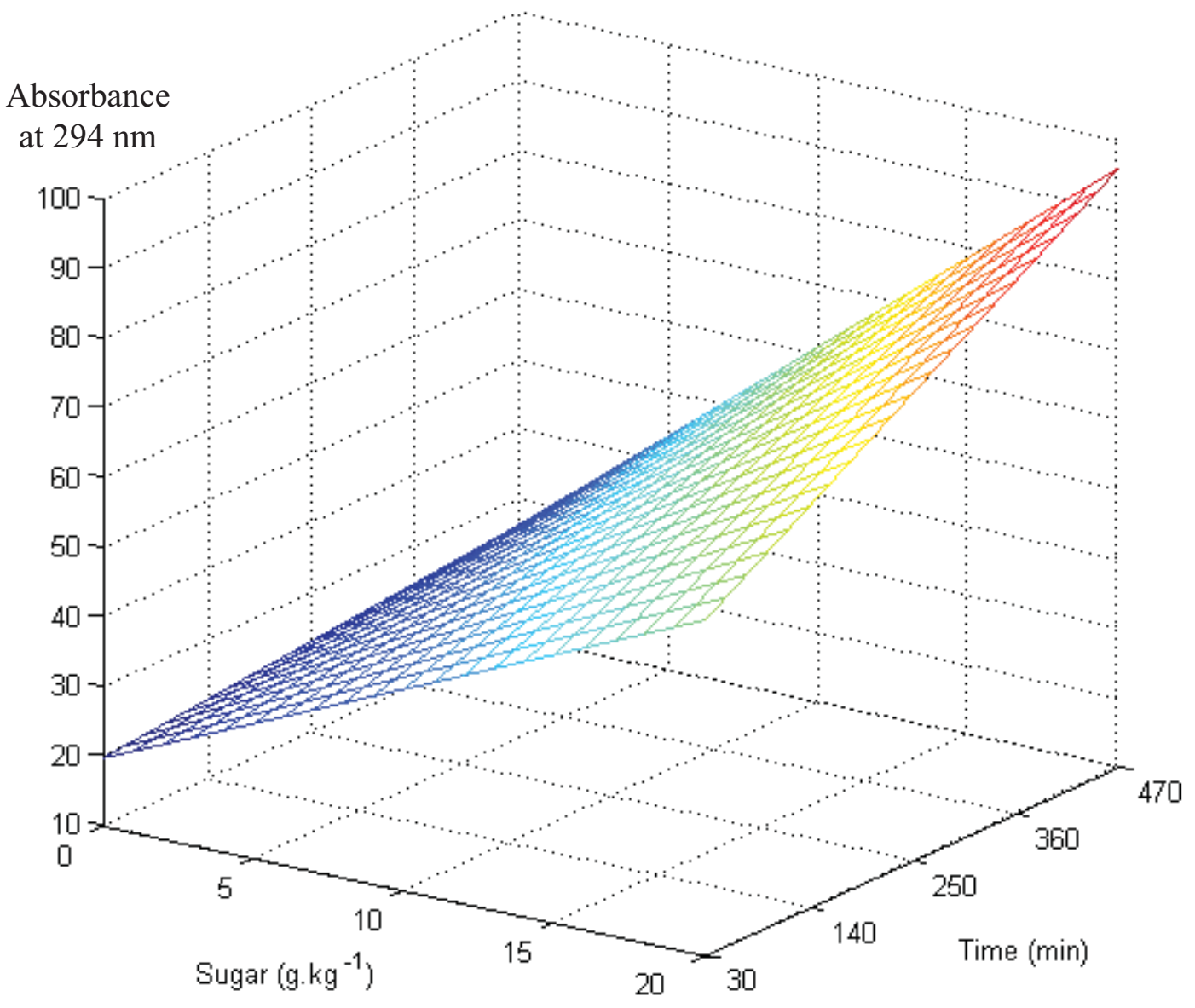




\section{ACCEPTED MANUSCRIPT}

Figure 3. Projection of variables in the plane 1-2 of the principal component analysis on sensory descriptors.

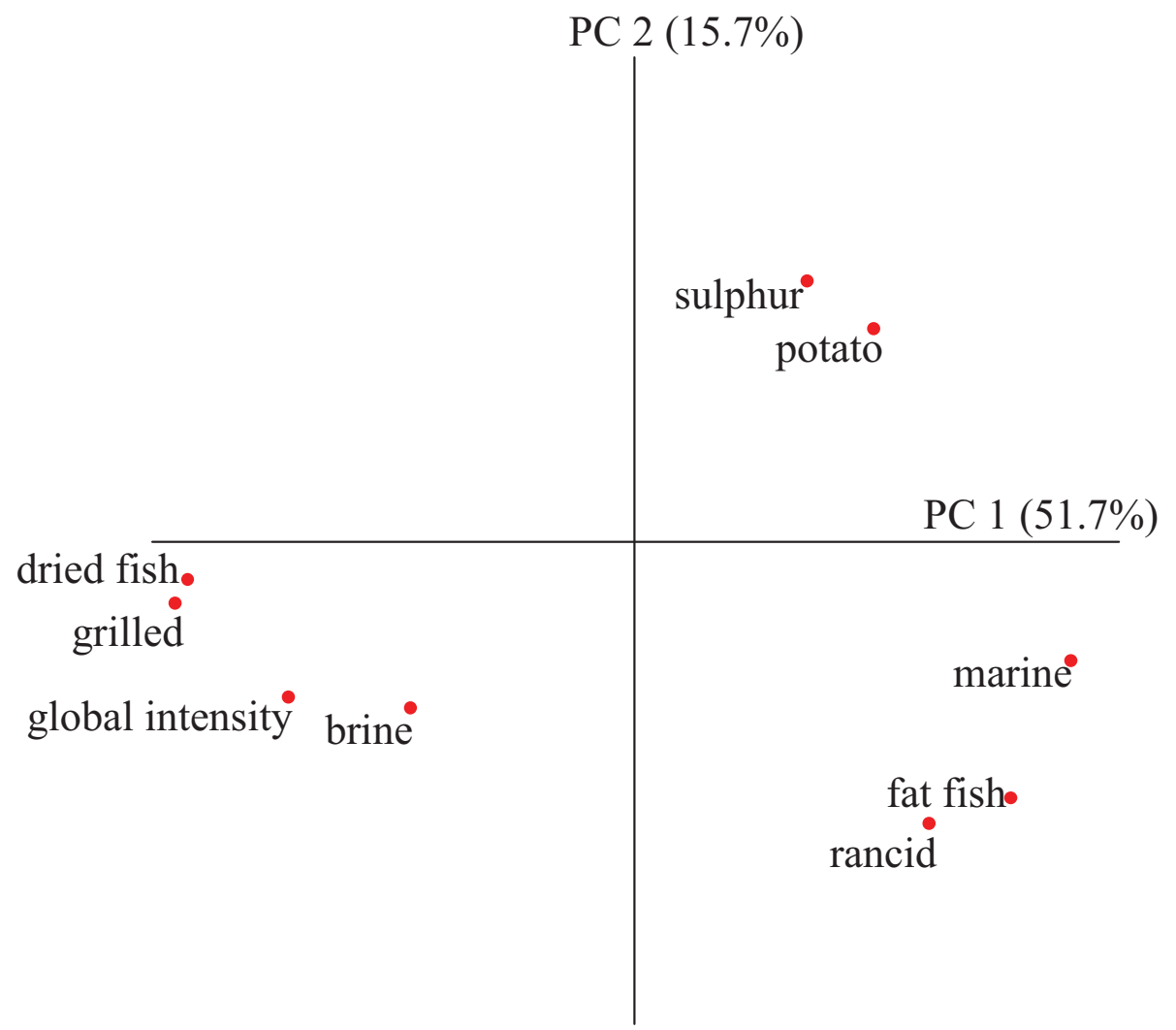




\section{ACCEPTED MANUSCRIPT}

Figure 4. Representation of products in the plane 1-2 of the principal component analysis.

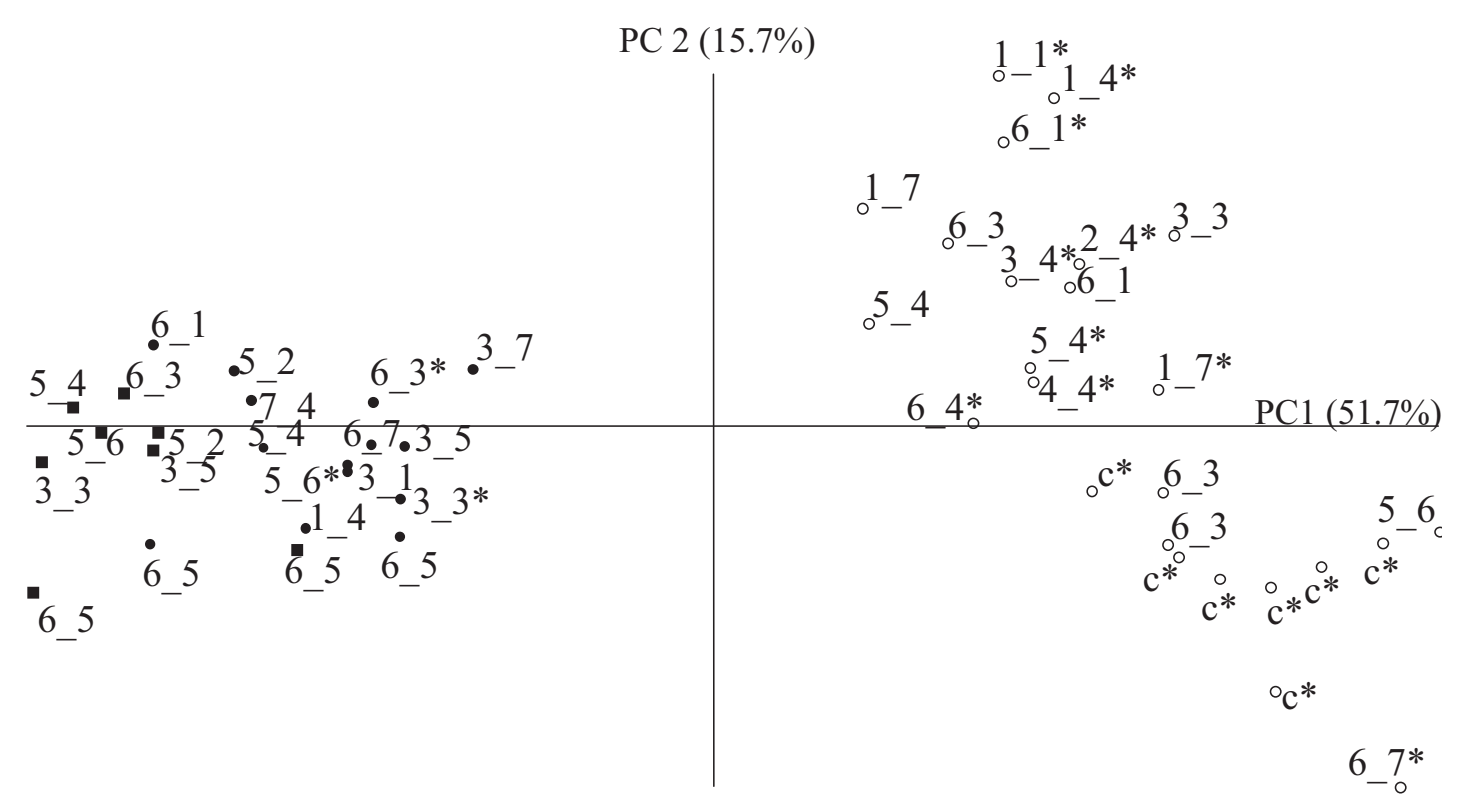

first number on the label refers to the hydrolysis time (min) used, $1=30,2=85,3=140,4=195$, $5=250,6=360,7=470$

second number on the label refers to the hydrolysis temperature $\left({ }^{\circ} \mathrm{C}\right)$ used, $1=30,2=35,3=40$, $4=45,5=50,6=55,7=60$

the level of sugar added is indicated by = ro sugar, $\quad 10 \mathrm{~g} \cdot \mathrm{kg}^{-1}, \quad=20 \mathrm{~g} \cdot \mathrm{kg}^{-1}$

samples without antioxidants are indicated with *

$\mathrm{c}=$ control sample prepared without enzyme at $60^{\circ} \mathrm{C}$ for $360 \mathrm{~min}$ 


\section{ACCEPTED MANUSCRIPT}

Figure 5. Response surface for soluble protein content as a function of temperature and hydrolysis time.

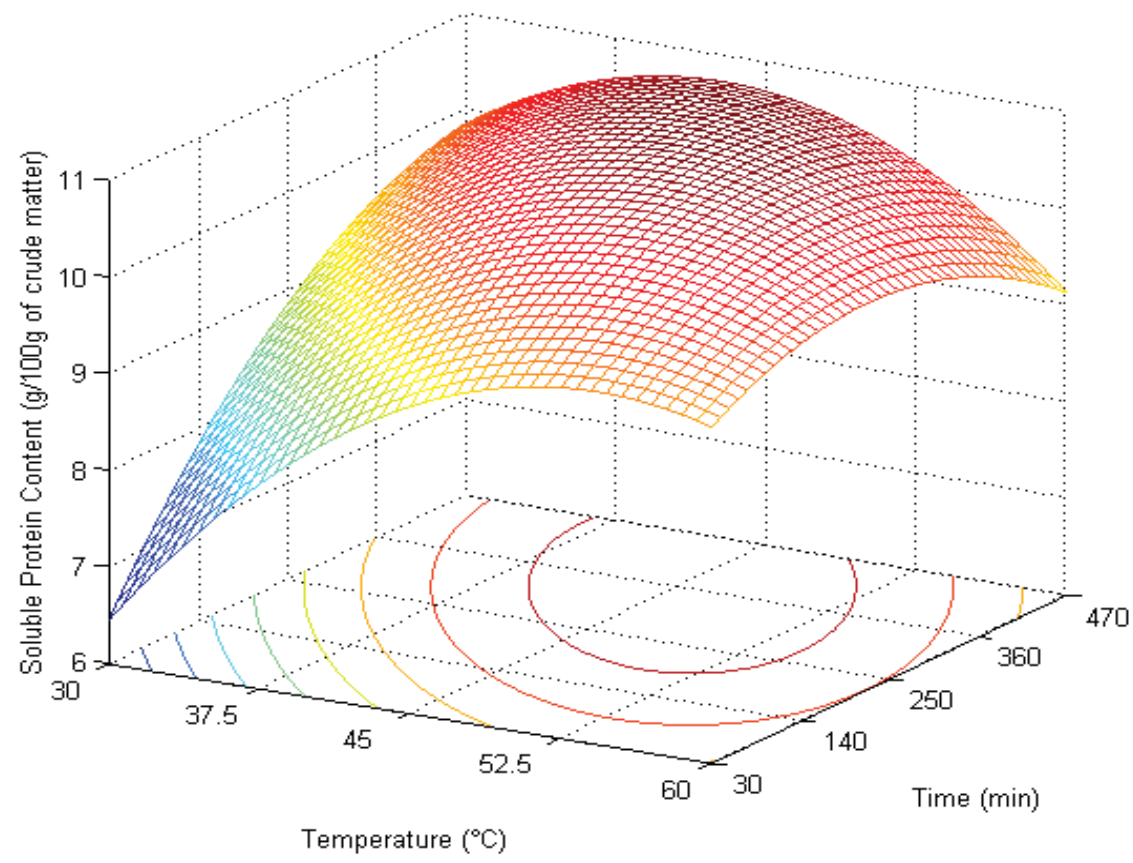




\section{ACCEPTED MANUSCRIPT}

Figure 6. Response surface for the grilled odor as a function of sugar concentration and hydrolysis time.

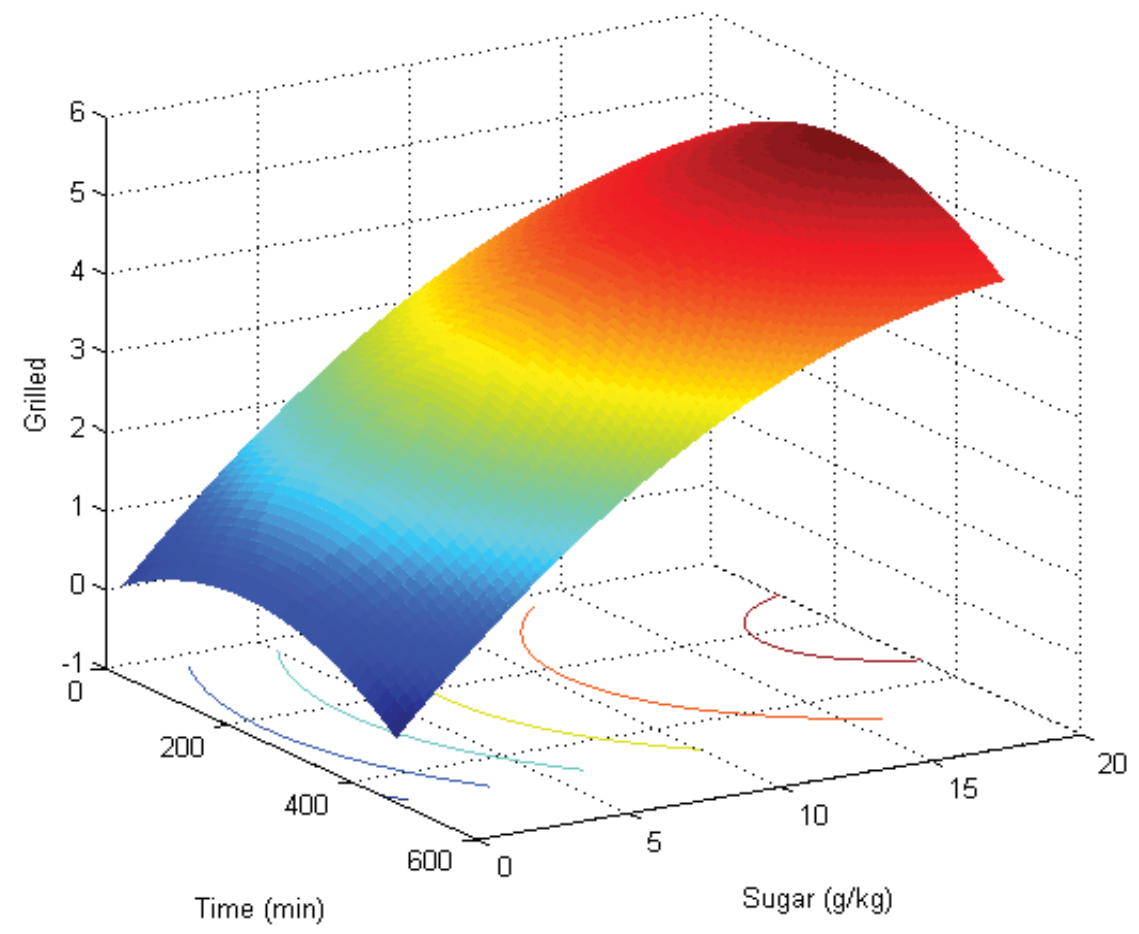




\section{ACCEPTED MANUSCRIPT}

Figure 7. Response surface for the grilled odor as a function of temperature and hydrolysis time for 10

sugar

g. $\mathrm{kg}^{-1}$ of

added.

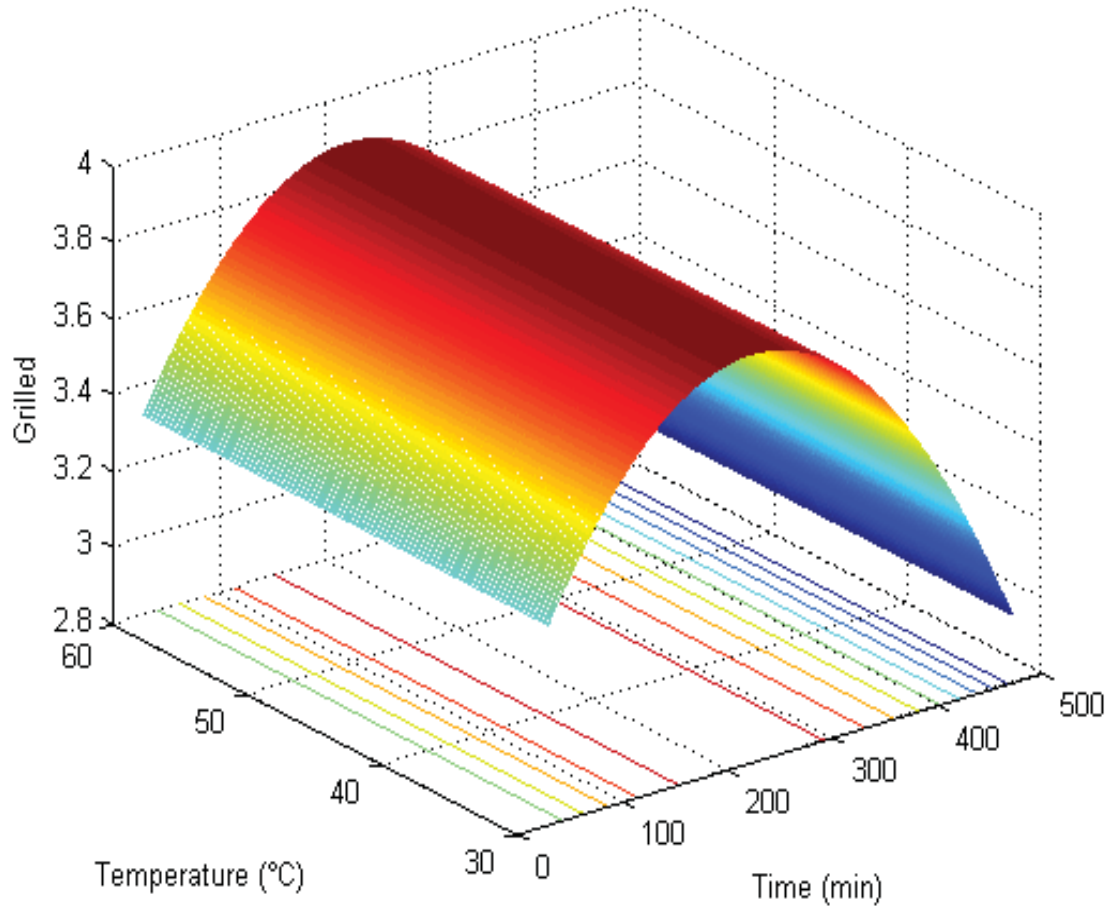

